Available online at GSC Online Press Directory

GSC Biological and Pharmaceutical Sciences

e-ISSN: 2581-3250, CODEN (USA): GBPSC2

Journal homepage: https://www.gsconlinepress.com/journals/gscbps

(RESEARCH ARTICLE)

\title{
Anti-inflammatory activity Keelvayu nivarana churnam in carrageenan induced inflammatory rats
}

\author{
Elango V. and Vijayabaskar G. * \\ Department of Siddha Medicine, Tamil University, Thanjavur, Tamil Nadu, S. India.
}

Publication history: Received on 17 August 2018; revised on 08 September 2018; accepted on 12 September 2018

Article DOI: https://doi.org/10.30574/gscbps.2018.5.1.0084

\begin{abstract}
Anti-inflammatory activity of Keelvayu nivarana churnam in carrageenan induced inflammatory rats was evaluated. Keelvayu nivarana churnam at the doses of $10,15 \mathrm{mg} / \mathrm{kg}$ and $25 \mathrm{mg} / \mathrm{kg}$ of body weight in experimental animals. Antiinflammatory activity was evaluated by Carrageenan induced paw edema in rats. Indomethacin ( $3 \mathrm{mg} / \mathrm{Kg}$ body weight) was employed as standard drug. Animals were randomized into 4 group $(n=6)$. Control group receives vehicle only. Keelvayu nivarana churnam treated with high dose which produced significant inhibition of edema and pain. This study confirms Keelvayu nivarana churnam possesses significant anti-inflammatory efficacy.
\end{abstract}

Keywords: Anti-inflammatory activity; Keelvayu nivarana churnam; Carrageenan; Indomethacin

\section{Introduction}

Inflammation is the body's challenge in the form of immune response to produce self-protection against the damages like cell destruction, irritability, infection etc. and begin the healing process. The inflammatory response consists of several physiological processes, all of which are triggered by the release of pharmacologically active substances such as histamine and heparin and the chemical mediators released from injured tissues and migratory cells [1]. Overproduction of auto antigens by denaturation of tissue proteins as in case of arthritis may also be one of the main causes for inflammatory reactions. Whatever may be cause for inflammation, all are characterized by four cardinal signs viz. redness, swelling, heat and pain. So, the goal of treatment for inflammation is to reduce or prevent the production of inflammatory agents that triggers the signs and symptoms of inflammation $[2,3]$.

Fortunately there are anti-inflammatory agents like cortisol naturally produced in the body and also available commercially. But these substances are known to produce some adverse side effects like suppression of natural immune system in the body [1] (Sembulingam and Prema Sembulingam, 2006). So, search is in progress to find out some natural herbs which may render anti-inflammatory action without producing any secondary problems. The present venture is one among them. Non-steroidal anti-inflammatory drugs (NSAIDs) are commercially available and are commonly used for treating chronic health problems like rheumatoid arthritis, osteoarthritis etc. But long term use of NSAIDS is also associated with side effects like stomach bleeding, allergic reactions, kidney problems, heart problems etc., [4]. According to Leopold, "There are natural alternatives to NSAIDs that have a similar mechanism; some of them include turmeric, green tea, ginger, rosemary, cat's claw, devil's claw, and willow bark" [5]. Thus, herbal medicines are maintaining their popularity not only for their historical and cultural reasons but also for their safety with minimum or nil side effects. Many safe, effective and challenging anti-inflammatory and analgesic drugs are available in Siddha system of medicine. The present work, attempts to report the preliminary results of studies on anti-inflammatory activity of Keelvayu nivarana churnam on Carrageenan induced inflammatory rats.

\footnotetext{
*Corresponding author

E-mail address: drgvijayabaskar@gmail.com
}

Copyright (C) 2018 Author(s) retain the copyright of this article. This article is published under the terms of the Creative Commons Attribution Liscense 4.0. 


\section{Material and methods}

\subsection{Animals}

Male albino rats of Wistar strain approximately weighing 180-220 were used in this study. They were healthy animals procured from Sri Venkateswara enterprises, Bangalore, India. The animals were housed in spacious polypropylene cages bedded with rice husk. The animal room was well ventilated and maintained under standard experimental conditions (Temperature $27 \pm 2{ }^{\circ} \mathrm{C}$ and 12 hours light / dark cycle) throughout the experimental period. All the animals were fed with standard pellet diet (Gold Mohur, Mumbai, India) and water ad libitum. They were acclimatization to the environment for 1 week prior to experimental use. The experiment was carried out according to the guidelines of the Committee for the Purpose of Control and Supervision of Experiments on Animals (CPCSEA), New Delhi, India.

\subsection{Preparation of Keelvayu nivarana churnam}

The ingredients of Keelvayu nivarana churnam are Nannariverppattai (Hemidesmus indicus), Parangipattai (Smilax china), Seemai Amukara (Withania somnifera) and Chittarthai (Alpinia officinarum). All the ingredients ground in to fine powder and mixed together in to the following ratio 10: 10: 10: 5 and used for study.

\subsection{Anti-inflammatory activity}

Anti-inflammatory activity was evaluated using the carrageenan induced rat paw oedema according to the technique of Winter et al., (1962) [6]. After $12 \mathrm{hrs}$ fast rats were divided into five groups of six each. Each animal was marked for identification and regularly monitoring. Group I served as control group received Carrageenan only. Group II, III and IV animals received Keelvayu nivarana churnam at a dose of 10,15 and $25 \mathrm{mg} / \mathrm{kg}$ orally. Group V was orally administered compound indomethacin ( $3 \mathrm{mg} / \mathrm{Kg}$ body weight) as a standard drug. The animals were pretreated with the extract half an hour before the administration of carrageenan. Acute inflammation was produced by the sub plantar administration of $0.1 \mathrm{ml}$ of $1 \%$ carrageenan in normal saline in the right paw of the control and experimental rats. The paw was marked with in at the level of lateral malleous and immersed in mercury up to the mark and measured by mercury volume displacement methods. The paw volume was measured $1 / 2,1,1 \frac{1}{2}$ and 2 hours after injection of carrageenan to each group. The difference between the readings was taken as the volume of oedema and the percentage of anti-inflammatory activity was calculated.

$$
\% \text { of inhibition rate }=\frac{V_{c}-V_{t}}{V_{c}} \times 100
$$

Where $V_{c}$ is the oedema value of the control group and $V_{t}$ is the oedema value of treated groups.

\section{Results and discussion}

Table 1 Effect of Keelvayu nivarana churnam on paw oedema in Carrageenan induced inflammatory rats

\begin{tabular}{llcccc}
\hline $\begin{array}{l}\text { Concentrations } \\
\text { (mg/Kg body weight ) }\end{array}$ & Group & \multicolumn{4}{c}{ Percentage of oedema inhibition (\%) } \\
\hline Control & & $\mathbf{1} \mathbf{2} \mathbf{~ h}$ & $\mathbf{1 ~ h}$ & $\mathbf{1 1} \mathbf{2} \mathbf{~ h}$ & $\mathbf{2 ~ h}$ \\
10 & Group I & -- & -- & -- & - \\
15 & Group II & 21.6 & 45.1 & 63.4 & 73.4 \\
25 & Group III & 35 & 56.1 & 74.5 & 81.9 \\
Standard (Indomethacin & Group IV & 42.42 & 66.2 & 82.9 & 89.8 \\
3 mg/kg) & Group V & 45.3 & 69.4 & 84.1 & 92.1 \\
\hline
\end{tabular}

Carrageenan induced inflammation is a biphasic phenomenon and is a useful model to detect oral actions of antiinflammatory agents. In the present study, the effect of Keelvayu nivarana churnam in carrageenan induced paw oedema was investigated. The rat's foot pad becomes oedemateous after injection of carrageenan. Administration of Keelvayu nivarana churnam reduces the paw oedema to inflammatory rats at a dose of $10 \mathrm{mg}, 15 \mathrm{mg}$ and $25 \mathrm{mg}(\mathrm{kg}$ body weight). The dose dependent a significant decrease of paw oedema and the reference drug indomethacin ( $3 \mathrm{mg} / \mathrm{kg}$ 
body weight) exhibited significant decrease (Table 1). Among the various doses, the $25 \mathrm{mg} / \mathrm{kg}$ (body weight) of Keelvayu nivarana churnam possess potential anti-inflammatory activity at $2 \mathrm{~h}$ as compared to other doses and nearest to the standard.

Inflammation has been identified as a reaction of living tissues to damage and it is known to include a complex variety of enzyme activation, mediator release, and extravasations of fluid, cell migration, tissue breakdown and repair [7]. The most extensively utilized primary test to display novel anti-inflammatory agents calculate the capability of a compound to decrease local oedema induced in the right paw by injection of an irritant agent [8]. Carrageenan-induced paw oedema in rats is a classical model of acute inflammation and commonly used in screening of drugs [9]. Growth of oedema in the paw of the rats after injection of carrageenan is a biphasic event. The early phase (1-2 h) of the carrageenan model is thought to be mostly mediated by histamine, serotonin and improved synthesis of prostaglandin in the injured tissue surroundings. The late phase $(3-4 \mathrm{~h})$ has been demonstrated to be sustained by prostaglandin release and mediated by bradykinins, leukotrienes, polymorphonuclear cells and prostaglandins produced by tissue macrophages. Cyclooxygenase plays a significant role in conversion of arachidonic acid into prostaglandins in the later inflammation phase in the carrageenan-induced oedema model which enzyme is considered to be a recognized target for a number of NSAIDs like aspirin.

The anti-inflammatory activity of Keelvayu nivarana churnam against carrageenan-induced paw oedema in rat revealed time and dose-dependent inhibition. The results showed that the extract at $25 \mathrm{mg} / \mathrm{kg}$ exhibited statistical significant activity comparable to control. The maximum inhibition of oedema volume was observed with $25 \mathrm{mg} / \mathrm{kg}$ of crude extract at $2 \mathrm{~h}$. The results indicated that Keelvayu nivarana churnam displayed relatively high anti-inflammatory effect by carrageenan. The data obtained from the present study indicate that Keelvayu nivarana churnam produced a dose dependent anti-inflammatory effect on carrageenan-induced paw oedema. At the dose of $25 \mathrm{mg} / \mathrm{kg}$, this effect was similar to that produced by the standard anti-inflammatory drug indomethacin. Our result agrees with the earlier report $[10,11$, and 12].

\section{Conclusion}

The present study on Keelvayu nivarana churnnam has significant anti- inflammatory properties and it justifies the traditional use of this churnnam in the treatment of various types of inflammation. This suggests that Keelvayu nivarana churnnam can be potentially used as a source of natural anti-inflammatory agent.

\section{Compliance with ethical standards}

\section{Acknowledgments}

We express our gratitude for the PhD, MPhil scholars of department of Siddha Medicine, Tamil University, Thanjavur for their kind help in carrying out the experiments and biochemical studies.

\section{Disclosure of conflict of interest}

The authors declare that there is no conflict of interests regarding the publication of this paper.

\section{Statement of ethical approval}

The animal experiments were performed after the approval from Institutional Animal Ethical Committee (IAEC) SASTRA University, Thanjavur (553/SASTRA/IAEC/RPP). The experiments were conducted according to the standard guidelines.

\section{References}

[1] Sembulingam K and Prema Sembulingam, (2012). Essentials of Medical Physiology, $6^{\text {th }}$ edition, Jay pee Brothers Medical Publishers (P) Ltd, 431-432.

[2] Opie EL. (1962). On the relation of necrosis and inflammation to denaturation of proteins. The Journal of Experimental Medicine, 115(3), 597-608.

[3] Umapathy E, Ndebia EJ, Meeme A, Adam B, Menziwa P, Nkeh-Chungag BN and Iputo JE. (2010). An experimental evaluation of Albuca setosa aqueous extract on membrane stabilization, protein denaturation and white blood cell migration during acute inflammation. Journal of Medicinal Plants Research, 4, 789-795. 
[4] American college of rheumatology NSAID; Treatment portal, https://www.rheumatology.org/I-Am-A/PatientCaregiver/Treatments/NSAIDs, last accessed on 08/05/2018

[5] Morgan Chris. (2002). Medicine of the Gods : Basic Principles of Ayurvedic Medicine, Mandrake publication, Chapter 1, 97-98

[6] Winter CA, Risley EA and Nuss GW, (1962 Dec). Carrageenin-induced edema in hind paw of the rat as an assay for anti-inflammatory drugs. Proceedings of the Society for Experimental Biology and Medicine, 111(3), 544547.

[7] Vane JR and Botting RM. (1995). New insights into the mode of action of anti-inflammatory drugs. Inflammation Research, 44(1), 1-10.

[8] Hernández-Pérez M and Rabanal Gallego RM. (2002). Analgesic and antiinflammatory properties of Sideritis lotsyivar Mascaensis. Phytotherapy Research, 16(3), 264-266.

[9] Christopher JM. (2003). Inflammation protocols. Humana Press Inc, 115-121

[10] Thenmozhi V, Elango V and Sadique J. (1989) Anti-inflammatory activity of some Indian medicinal plants., Ancient Science of Life, 8(3\&4), 258-261

[11] Syed Ismail T, Gopalakrishnan S, Hazeena Begum V and Elango V. (1997). Anti-inflammatory activity of Salacia oblonga Wall. and Azima tetracantha Lam. Journal of Ethnopharmacology, 56(2), 145-152

[12] Sadique J, Chandra T, Thenmozhi V and Elango V. (1987). Biochemical modes of action of Cassia occidentalis and Cardiospermum halicacabum in inflammation. Journal of Ethnopharmacology, 19(2), 201-212.

\section{How to cite this article}

Elango V and Vijayabaskar G. (2018). Anti-inflammatory activity of Keelvayu nivarana churnam in carrageenan induced inflammatory rats. GSC Biological and Pharmaceutical Sciences, 5(1), 17-20. 